\title{
PHYSICAL BINDING OF INSULIN BY GAMMA GLOBULINS OF INSULIN-RESISTANT SUBJECTS ${ }^{1,2}$
}

\author{
By BELTON A. BURROWS, THEODORE PETERS, ${ }^{3}$ AND FRANCIS C. LOWELL with \\ THE TECH NICAL ASSISTANCE OF ANNE N. TRAKAS AND PAUL REILLY \\ (From the Radioisotope Service, Boston Veterans Administration Hospital, the Robert Dawson \\ Evans Memorial, Massachusetts Memorial Hospitals, the Department of Medicine, \\ Boston University School of Medicine, and the Department of Biological \\ Chemistry, Harvard Medical School, Boston, Mass.)
}

(Submitted for publication July 2, 1956 ; accepted November 15, 1956)

The occasional occurrence of resistance to insulin among certain diabetic patients has been recognized for many years. However, the immunologic nature of this resistance, which may require the administration of over 1,000 units of insulin per day, has been demonstrated only by indirect means (2). Serum of insulin-resistant patients has been shown to protect mice from the hypoglycemic effect of insulin $(3,4)$, and to prevent the in vitro action of insulin on the rat diaphragm (5). The insulin-neutralizing property of such serum has been shown by electrophoretic $(6,7)$ and salt (8) fractionation to reside in the gamma globulin fraction. The substances in the plasma, presumably antibodies, related to the capacity of insulin to produce urticaria and allied reactions are apparently distinct from the insulin-neutralizing substances, and have been shown to reside in the beta globulin fraction (6).

Using $\mathrm{I}^{131}$-labeled insulin, this study has shown that serum of insulin-resistant subjects, but not of normal individuals or non-resistant diabetic patients, complexes insulin and that this complex migrates at the leading edge of the gamma globulin fraction upon paper electrophoresis. By adding progressively larger amounts of insulin, it was possible, in most cases, to estimate the concentration of insulin needed to saturate such sera. Seventeen serum specimens from four insulin-resistant persons and one insulin-resistant rabbit were found

\footnotetext{
${ }^{1}$ Supported by AEC Contract At (30-1)-919 between the Atomic Energy Commission and the Massachusetts Memorial Hospitals.

2 This work has appeared in abstract form (1), and was presented at the New England V.A. Clinical Research Society Meeting, Sturbridge, Massachusetts, October 7, 1955.

3 Present address : The Mary Imogene Bassett Hospital, Cooperstown, New York.
}

to bind insulin in amounts from $0.05 \mu \mathrm{gm}$. to more than $20 \mu \mathrm{gm}$. per $\mathrm{ml}$.

\section{MATERIALS AND METHODS}

Preparation of labeled insulin. Insulin labeled with $\mathrm{I}^{131}$ and containing $3 \mu \mathrm{c}$. of $\mathrm{I}^{131}$ per $\mu \mathrm{gm}$. and about 0.6 atom of iodine per 24,000 molecular weight was prepared by a modification of the basic method of Banks, Seligman, and Fine (9). A mixture was made of $0.15 \mathrm{ml}$. of $\mathrm{KI}$, containing $15 \mu \mathrm{gm}$. I, with $0.02 \mathrm{ml}$. of $\mathrm{KIO}_{3}$ containing $3 \mu \mathrm{gm}$. of I in a $2-\mathrm{ml}$. glass stoppered tube. To this was added $\mathrm{KI}^{131}$ containing $14.8 \mu \mathrm{c}$. and about $0.12 \mu \mathrm{gm}$. of I followed by $0.1 \mathrm{ml}$. of $1 \mathrm{~N} \mathrm{HCl}$. After the addition of $\mathrm{CCl}_{4}$ the contents were shaken periodically for 10 to 15 min., during which time about 80 per cent of the I was extracted as $\mathrm{I}_{2}$ into the $\mathrm{CCl}_{4}$ layer. The upper (aqueous) layer was removed by a dropper and $0.1 \mathrm{ml}$. of $0.12 \mathrm{~N}$ $\mathrm{Na}_{2} \mathrm{CO}_{3}$ containing $1 \mathrm{mg}$. crystalline bovine insulin ${ }^{4}$ was added. The tube was shaken and allowed to stand for one hour.

Unreacted iodine was removed by treatment with an anion exchange resin. The insulin solution was diluted with $0.4 \mathrm{ml}$. of $\mathrm{pH} 7.4$ buffer, containing $0.11 \mathrm{~N} \mathrm{NaCl}$ and $0.04 \mathrm{M}$ veronal, and placed on a $0.8 \times 12 \mathrm{~cm}$. column of Amberlite IRA 410, which had been saturated with $\mathrm{HCl}$ and adjusted to $\mathrm{pH} 7.4$ prior to use. The insulin was washed through the column with the buffer, and finally made to $10.0 \mathrm{ml}$. with buffer. Yield was 20 per cent of the $\mathrm{I}^{181}$ used. Less than 4 per cent of the radioactivity of the insulin could be removed by prolonged dialysis. The $\mathrm{I}^{131}$-labeled insulin was used within a week of its preparation to minimize the possibility of radiation damage to the insulin. At concentrations less than $10 \mu \mathrm{gm}$. per $\mathrm{ml}$. the insulin was found to adsorb appreciably onto glass containers, so it was not diluted until just before use.

Testing procedure. After $0.02 \mathrm{ml}$. of labeled insulin solution, containing from 5 to $100 \mu \mathrm{gm}$. of insulin per $\mathrm{ml}$ was added to $0.2 \mathrm{ml}$. of serum, $0.02 \mathrm{ml}$. of this mixture, or $0.2 \mu \mathrm{gm}$. of insulin, was applied in a narrow band across a $3-\mathrm{cm}$. strip of Whatman No. $3 \mathrm{MM}$ paper in the electrophoresis apparatus. A similar volume of the mix-

4 Armours $5 \times$ recrystallized bovine insulin, graciously supplied by Dr. E. G. Ball of the Department of Biological Chemistry, Harvard Medical School. 
ture was delivered into $1 \mathrm{ml}$. of water for subsequent determination of the exact amount of $\mathrm{I}^{131}$-insulin present by gamma ray counting. The paper strips had been previously wet with the buffer (veronal, $\mathrm{pH} 8.6$, ionic strength 0.05 ) and allowed to equilibrate for 20 to 40 minutes in the apparatus. The electrophoresis equipment was of a conventional type employing horizontally suspended strips, with a free length of $38 \mathrm{~cm}$. between electrode baths. About $5 \mathrm{v}$. per $\mathrm{cm}$. of free length were applied for 14 to 18 hours at room temperature. The strips were then dried in an oven at $95^{\circ} \mathrm{C}$ for 30 minutes.

\section{RESULTS}

In Figure 1 are shown typical results on different types of sera. Insulin labeled with radioiodine was detected by exposing the strips against $\mathrm{X}$-ray film for 1 to 8 days. Proteins were subsequently detected by staining with 0.25 per cent bromphenol blue in $9 / 1$ methanol/acetic acid, and rinsing in 30/3/1 water/acetic acid/phenol.

The findings agreed with those of Kallee (10, 11 ) in that insulin in these low concentrations, whether tested alone or mixed with normal serum, did not migrate upon electrophoresis, but remained adsorbed to the paper at the starting point (Figure 1, strips 1 and 2). Migration of free insulin could be obtained by adding a large excess of insulin, also shown by Kallee. In these cases the $\mathrm{I}^{131}$-insulin migrated with a mobility about equal to that of serum albumin, but exchange between the labeled and non-labeled insulin and adsorption along the strips resulted in smearing and trailing of the labeled insulin. Hence, the more precise test for binding of insulin was to examine strips for movement of insulin which otherwise would have remained adsorbed at the starting point.

Strips 3, 4 and 5 of Figure 1 show binding of the $\mathrm{I}^{131}$-insulin by the sera of three patients who were resistant to insulin. In strips 3 and 4 the insulin is completely bound so that none remains at the starting point. In strip 5 the serum has apparently been saturated, so that only a portion of the insulin moves. Insulin which is bound moves with the leading portion of the gamma globulins, suggesting that the insulin is complexed by gamma globulins into a soluble molecule with a mobility intermediate between the mobilities of free insulin and free gamma globulin.

In the detailed studies of Singer and Campbell $(12,13)$ on the physical chemical properties of soluble antigen-antibody complexes of ovalbumin and bovine serum albumin with their rabbit antibodies, it was shown that the electrophoretic mobilities of complexes were intermediate between

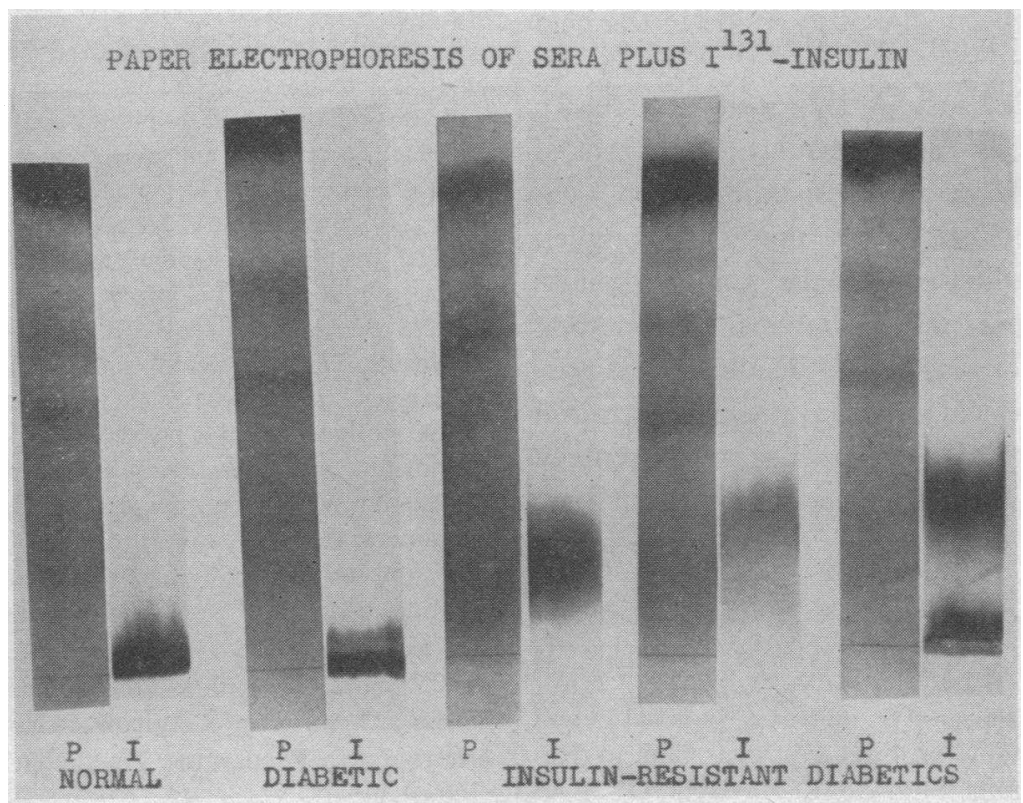

Fig. 1. Electrophoresis of I ${ }^{181}$-Insulin Mixed with Various Sera

Strips labeled "P" are stained to show the protein fractions. Radioautographs of the same strips are labeled "I." 
the mobilities of the free antigen and antibody, and could be predicted on the basis of the weight fraction of each component in the complex. From rough measurements of the relative mobilities on paper of free insulin (on insulin-treated papers), gamma globulin, and complexed $\mathrm{I}^{131}$-insulin, it can be calculated on this basis that insulin comprises only 7 to 13 per cent of the weight of the complex. Assuming a molecular weight of 170,000 for the gamma globulin, this would mean that the complex contains one-half to one insulin molecule of molecular weight 24,000 per one gamma globulin molecule.

\section{Quantitative measurements}

For routine testing, radioautographs were not made, but the labeled insulin was located by passing the strip under a $1.9 \mathrm{mg}$. per sq. $\mathrm{cm}$. end window Geiger counter, equipped with a lead cover containing a $0.5-\mathrm{cm}$. slit. Radioactivity was measured every 0.5 or $1 \mathrm{~cm}$. of length along the paper strip, and the curve of radioactivity versus distance along the strip plotted. Movement of the labeled insulin could be detected by comparing the curve with the strip after staining to locate the protein fractions. When only part of the insulin migrated, the amount which migrated was estimated by determining the areas under the two curves with a planimeter.

In varying the insulin concentration to determine the saturation limit of the sera, the insulin concentration was not allowed to exceed $10 \mu \mathrm{gm}$. per ml. of serum. To avoid exceeding this level, the sera under investigation was diluted with varying amounts of serum from normal individuals. This also avoided the possibility of exceeding the saturation limit of the paper, when insulin would migrate in the free form.

Table I shows the results with various types of subjects. Eight normal persons and seven diabetic patients who were not resistant to insulin showed no migration of $\mathrm{I}^{131}$-insulin with the gamma globulins, the level of detection being approximately $0.02 \mu \mathrm{gm}$. or 0.0007 unit of insulin per ml. serum. The sera of four insulin-resistant patients, and of a rabbit immunized against crystalline beef and pork insulin by one of the authors in a previous study (14), showed binding of insulin in ranges of 0.4 to $20 \mu \mathrm{gm}$. per $\mathrm{ml}$. Some of the specimens had been stored frozen, with several thawings, for periods up to 15 years, but still gave satisfactory electrophoretic patterns.

Occasional modifications of the response were noted, such as a suggestion of a peak trailing the serum proteins (Figure 1, strip 4), or "tailing" or movement of the baseline. These modifications were seen occasionally with sera of resistant patients when large amounts of insulin were added, and were never seen with normal sera or with sera of diabetic patients who were not resistant to insulin, except in one specimen from a diabetic patient which showed a slightly increased tailing of the baseline. These effects may represent partial binding by serum with weak forces of the same order as the adsorption affinity of insulin for the paper.

With one patient it was possible to compare the amounts of insulin bound with the insulin requirement and the results of mouse protection tests on the same serum specimens (Table I). The periods of resistance to insulin as shown by the requirement for insulin and mouse test correspond with periods of high binding of insulin by the gamma globulins.

\section{Species specificity}

Table II shows evidence of species specificity of the insulin binding, when tested by adding nonlabeled human insulin in addition to the labeled bovine insulin to sera from insulin-resistant subjects. The amount of binding of $\mathrm{I}^{131}$-bovine insulin which was observed was not reduced by the addition of human insulin to the degree expected if the two insulins were equally bound. This preferential binding of $\mathrm{I}^{131}$-bovine insulin is in agreement with the finding $(15,16)$ that human insulin was effective in controlling the blood sugar in patient A. M. when large doses of bovine insulin were ineffective and in lowering the blood sugar in Rabbit No. 5 (14) when equivalent or larger doses of bovine insulin had no effect.

Recent reports have indicated $(17,18)$ that sera of insulin-treated diabetic patients, who showed no clinical resistance to insulin, bound labeled insulin either in vivo or in vitro so that it migrated with or just ahead of the gamma globulins. The present study has not demonstrated binding of insulin by gamma globulins in any of 
TABLE I

$I^{131-i n s u l i n ~ b o u n d ~ b y ~ s e r u m ~ p r o t e i n s ~}$

\begin{tabular}{|c|c|c|c|c|c|c|}
\hline \multirow[b]{2}{*}{ Subject } & \multirow[b]{2}{*}{ Date } & \multirow{2}{*}{$\underset{\substack{\text { Clinical } \\
\text { insulin } \\
\text { resistance* }}}{ }$} & \multicolumn{2}{|c|}{$\begin{array}{c}\text { Insulin dose } \\
\text { administered } \dagger\end{array}$} & \multirow{2}{*}{$\begin{array}{l}\text { Insulin neut. } \\
\text { by mouse test }\end{array}$} & \multirow{2}{*}{$\begin{array}{c}\text { Insulin bound by } \\
\text { gamma glob. } \\
\text { (ugm./ml.) }\end{array}$} \\
\hline & & & Units/day & Type & & \\
\hline 8 normals & & & 0 & & & 0 . \\
\hline 7 diabetics & & & $0-46$ & NPH & & $0 \S$ \\
\hline A. M. & $\begin{array}{c}2 / 11 / 42 \\
3 / 2 / 42 \\
8 / 18 / 42 \\
11 / 4 / 42 \\
4 / 19 / 44 \\
5 / 25 / 44\end{array}$ & $\begin{array}{l}? 0 \\
+ \\
? 0 \\
0 \\
0 \\
+\end{array}$ & $\begin{array}{c}0 \\
800+ \\
35 \\
35 \\
0-96 \ddagger \\
280+\end{array}$ & $\begin{array}{l}\text { Reg. } \\
\text { Reg. } \\
\text { Reg. } \\
\text { Reg. } \\
\text { Reg. } \\
\text { Reg. }\end{array}$ & $\begin{array}{l}0 \\
+ \\
? \\
0 \\
0 \\
+\end{array}$ & $\begin{array}{c}0.05 \\
10+ \\
0.05 \\
0 \text { (tailing) } \\
0 \text { (tailing) } \\
20\end{array}$ \\
\hline C. & $\begin{array}{r}4 / 13 / 44 \\
9 / 10 / 44 \\
12 / 17 / 44\end{array}$ & $\begin{array}{l}+ \\
+ \\
+\end{array}$ & $\begin{array}{l}\text { ca. } 300 \\
\text { ca. } 300 \\
\text { ca. } 300\end{array}$ & $\begin{array}{l}\text { Reg. } \\
\text { Reg. } \\
\text { Reg. }\end{array}$ & & $\begin{array}{l}0.8+ \\
0 \text { (tailing) } \\
1+\end{array}$ \\
\hline M. & $\begin{array}{l}9 / 7 / 44 \\
9 / 21 / 44 \\
4 / 15 / 48 \\
8 / 8 / 55\end{array}$ & $\begin{array}{l}+ \\
+ \\
+ \\
?\end{array}$ & $\begin{array}{l}\text { ca. } 500 \\
\text { ca. } 500 \\
\text { ca. } 500 \\
100\end{array}$ & $\begin{array}{l}\text { Reg. } \\
\text { Reg. } \\
\text { Reg. } \\
\text { Reg. }\end{array}$ & & $\begin{array}{l}1.5 \\
1.2 \\
0.6+ \\
0.14\end{array}$ \\
\hline o. & $\begin{array}{l}3 / 23 / 54 \\
4 / 24 / 54\end{array}$ & + & $\begin{array}{l}\text { ca. } 300 \\
\text { ca. } 300\end{array}$ & $\begin{array}{l}\text { Reg. } \\
\text { Reg. }\end{array}$ & & $\begin{array}{l}0.2 \\
0.4\end{array}$ \\
\hline $\begin{array}{l}\text { Rabbit "No. 5" } \\
\text { Rabbit "No. 5" (14) }\end{array}$ & $\begin{array}{l}9 / 26 / 47 \\
3 / 23 / 48\end{array}$ & + & $\begin{array}{l}\text { (Immunize } \\
\text { (Immunize }\end{array}$ & $\begin{array}{l}\text { Cryst. } \\
\text { Cryst. }\end{array}$ & & $\begin{array}{l}0.2 \\
0.4\end{array}$ \\
\hline
\end{tabular}

* Presence of clinical resistance indicated by "+", absence of resistance by " 0 ". A "?" indicates that no direct test for resistance was done, but because of considerations discussed elsewhere (2), resistance was probably present or absent as indicated.

t The amount of insulin given does not necessarily reflect the insulin requirement, in that the patient may not have been completely controlled by the insulin dose indicated.

$\ddagger$ Insulin therapy resumed two days previously, 31 to 96 units per day.

$\$$ One specimen showed slight tailing of the adsorbed band.

the seven diabetics who were not resistant to insulin. No obvious reason could be found for this difference in results, but it might be related to 1) difference in sensitivity of detection of binding, 2) the use of bovine insulin in this study instead of the commercial mixture of beef and pork

TABLE II

Preferential binding of $I^{131}$-bovine insulin in the presence of human insulin

\begin{tabular}{lccc}
\hline \hline & \multicolumn{2}{c}{ Irs-bovine insulin } & \\
\cline { 2 - 3 } Subject & $\begin{array}{c}\text { Added } \\
(\mu g m . / m l .)\end{array}$ & $\begin{array}{c}\text { Bound } \\
(\mu g m . / m b .)\end{array}$ & $\begin{array}{c}\text { Human insulin } \\
\text { added } \\
(\mu g m . / m b .)\end{array}$ \\
\hline O. 3/23/54 & 0.48 & 0.24 & 0 \\
& 0.44 & 0.23 & 0.44 \\
A. M. 5/25/44 & 9 & 9 & 0 \\
& 60 & 22 & 0 \\
& 4 & 3.1 & 35 \\
Rabbit No. 5 & 0.48 & 0.15 & 0 \\
& 0.54 & 0.14 & 0 \\
& 0.44 & 0.11 & 0.44 \\
\hline
\end{tabular}

insulin or 3) lower antigenicity of the NPH-insulin received by all but one of the non-insulin-resistant diabetic patients reported here.

The technique described offers a sensitive method of testing for the presence of non-precipitating antibodies. It is somewhat similar to the technique of precipitation of labeled antigen with ammonium sulfate employed for this purpose by Farr (19), but differs from the paper electrophoresis technique used by others (20) for the detection of antibodies against DNP-beta-lactoglobulin, which depended upon the complexed antigen being rendered immobile by antibodies, apparently precipitin in nature. The above technique may be of value in testing for antibodies to protein hormones other than insulin.

\section{SUMMARY}

1. When $I^{131}$-labeled bovine insulin was added in vitro to serum from insulin-resistant persons the insulin was found to migrate with the leading edge 
of the gamma globulin zone upon paper electrophoresis. Similar migration was not seen with serum from normal persons or diabetic patients who were not resistant to insulin. This suggests that the insulin resistance was due to the presence of antibodies which bound insulin into an inactive but soluble complex.

2. Insulin binding capacity amounted to 0.05 to more than $20 \mu \mathrm{gm}$. per ml. of serum. Evidence that human insulin was not bound in this manner is presented.

\section{REFERENCES}

1. Peters, T., Burrows, B. A., and Lowell, F. C., Physical binding of insulin by gamma globulins from insulin-resistant subjects. Federation Proc., 1956, 15, 608 (Abstract).

2. Eskind, I. B., Franklin, W., and Lowell, F. C., Insulin-resistant diabetes mellitus associated with hemochromatosis. Ann. Int. Med., 1953, 38, 1295.

3. Lowell, F. C., Immunologic studies in insulin resistance. II. The presence of a neutralizing factor in the blood exhibiting some characteristics of an antibody. J. Clin. Invest., 1944, 23, 233.

4. Lowell, F. C., Immunologic studies in insulin resistance. III. Measurement of an insulin antagonist in the serum of an insulin-resistant patient by the blood sugar curve method in mice. J. Clin. Invest., 1947, 26, 57.

5. Marsh, J. B., and Haugaard, N., The effect of serum from insulin-resistant cases on the combination of insulin with the rat diaphragm. J. Clin. Invest., 1952, 31, 107.

6. Loveless, M. H., and Cann, J. R., Distribution of "blocking" antibody in human serum proteins fractionated by electrophoresis-convection. J. Immunol., 1955, 74, 329.

7. Sehon, A. H., Kaye, M., McGarry, E., and Rose, B., Localization of an insulin-neutralizing factor by zone electrophoresis in a serum of an insulin-resistant patient. J. Lab. \& Clin. Med., 1955, 45, 765.

8. De Filippis, V., and Iannaccone, A., Insulin-neutralizing activity of gamma-globulins derived from the serum of an insulin-resistant patient. Lancet, 1952, 1, 1192.
9. Banks, H. H., Seligman, A. M., and Fine, J., Theeffect of hyaluronidase on the absorption of parenterally administered radioactive plasma proteins in the dog. J. Clin. Invest., 1949, 28, 548.

10. Kallee, E., Uber ${ }^{181} \mathrm{~J}$-signiertes Insulin, I. Mitteilung: (Nachweis). Ztschr. f. Naturforsch., 1952, 7B, 661.

11. Kallee, E., Uber ${ }^{181} \mathrm{~J}$-signiertes Insulin, II. Anwendungsbereich und Grenzen der Nachweismethode. Klin. Wchnschr., 1954, 32, 508.

12. Singer, S. J., and Campbell, D. H., Physical chemical studies of soluble antigen-antibody complexes. IV. The effect of $\mathrm{pH}$ on the reaction between bovine serum albumin and its rabbit antibodies. J. Am. Chem. Soc., 1955, 77, 3504.

13. Singer, S. J., and Campbell, D. H., Physical chemical studies of soluble antigen-antibody complexes. V. Thermodynamics of the reaction between ovalbumin and its rabbit antibodies. J. Am. Chem. Soc., 1955, 77, 4851.

14. Lowell, F. C., and Franklin, W., Induced insulin resistance in the rabbit. J. Clin. Invest., 1949, 28, 199.

15. Lowell, F. C., Evidence for the existence of two antibodies for crystalline insulin. Proc. Soc. Exper. Biol. \& Med., 1942, 50, 167.

16. Lowell, F. C., Immunologic studies in insulin resistance. I. Report of a case exhibiting variations in resistance and allergy to insulin. J. Clin. Invest., 1944, 23, 225.

17. Berson, S. A., Yalow, R .S., Bauman, A., Rothschild, M. A., and Newerly, K., Insulin- ${ }^{181}$ metabolism in human subjects: Demonstration of insulin binding globulin in the circulation of insulin treated subjects. J. Clin. Invest., 1956, 35, 170.

18. Weiger, R. W., and Colwell, A. R., The inhibition of insulin action by serum gamma globulin. Clin. Research Proc., 1956, 4, 123.

19. Farr, R. S., Measurement of antigen-combining capacity of antiserums as determined by ammonium sulfate precipitation of $\mathrm{I}^{131}$ antigen after complex formation with antibody. Federation Proc., 1956, 15, 586 (Abstract).

20. Eisen, H. N., Penefsky, H. S., and Tabachnik, M., Detection of antibody-antigen interaction by means of electrophoresis in paper. Federation Proc., 1955, 14, 461 (Abstract). 